\title{
Assessment of the Mechanism for Ensuring the Effectiveness of Marketing Activities
}

\author{
Marta Kopytko ${ }^{1}$ *0000-0001-6598-3798], Tetiana Arestenko 2 [0000-0003-0757-6494] \\ ${ }^{1}$ Lviv State University of Internal Affairs, Lviv, Ukraine \\ ${ }^{2}$ Dmytro Motornyi Tavria State Agrotechnological University. Melitopol, Ukraine \\ *marta_kernytska@ukr.net
}

\begin{abstract}
In modern economic conditions, managers, scientists and practitioners face the question of the development and application of quality principles, approaches, methods of competition and the latest technologies in managing the marketing activities of enterprises in the advertising industry. The organizational and economic mechanism for ensuring the effectiveness of the marketing activities of enterprises in the advertising industry is an element of an integrated management mechanism, which provides for the formation and strengthening of the enterprise's potential through influencing the organizational parameters of the system and the economic elements of the enterprise's production activities. An effective organizational and economic mechanism of marketing activities is the basis for overcoming crisis phenomena and one of the conditions for the successful functioning of enterprises in the advertising industry.
\end{abstract}

Keywords: marketing, enterprises, mechanism, assessment, ensuring.

\section{INTRODUCTION}

At the present stage of development of the Ukrainian economy, the role of managing the marketing activities of enterprises is increasing. An integral element of effective entrepreneurial activity is the understanding and use of the concept of marketing in enterprise management. The qualitative component of marketing in management is huge, since it predetermines the highly profitable rhythmic activity of business entities.

Marketing management is the process of planning and implementing a pricing policy, promoting and developing ideas, products and services aimed at making exchanges that satisfy both individuals and the firm. It also aims to solve the problems of the firm's impact on the level and structure of demand in a certain period of time, to determine the optimal balance of supply and demand for the firm to achieve its goal.

An important aspect of the end result of the marketing activities of enterprises in the advertising industry is the effectiveness of the organizational and economic mechanism [1-5]. To determine the degree of influence on the final result, it is necessary to assess the effectiveness of the organizational and economic mechanism of enterprises in the advertising industry. It should be emphasized that the assessment requires a methodology that would make it possible to quantitatively assess the qualitative parameters of the organizational and economic mechanism of such enterprises.

The relevance of using the marketing mechanism for the development of an organization is due to the problems of modern marketing associated with the need to adapt products to the needs of certain consumers, who have become more discriminating and increasingly ignore commercial offers, and the only way to attract their attention is to develop a new marketing mechanism for developing the organization's business activities [6-9].

The organizational and economic mechanism for ensuring the effectiveness of the marketing activities of enterprises in the advertising industry is an element of an integrated management mechanism, which provides for the formation and strengthening of the enterprise's potential through influencing the organizational parameters of the system and the economic elements of the enterprise's production activities [10-14]. Emphasizing that this can be done through the interaction of methods, relationships, principles, bases, management levers, with the help of which the goals facing the enterprise of the advertising industry are effectively 
realized, we propose to determine the effectiveness of each component of the mechanism.

\section{THE EFFECTIVENESS OF THE MECHANISM FOR ENSURING THE EFFECTIVENESS OF THE MARKETING ACTIVITIES OF ENTERPRISES}

The absolute indicator for assessing the effectiveness of the mechanism of marketing activities of organizations in the advertising industry $(\mathrm{P})$ is determined by the sum of factors (1):

$$
P=\sum_{i=1}^{3} m_{i} F_{i},
$$

where $_{i}=1 \ldots 3-$ is the number of factors,

$\mathrm{m}_{\mathrm{i}}-$ is the weight of the $\mathrm{i}$-th factor;

$F_{i}-$ is the $i$-th factor influencing the integral state and is determined by the state of the individual components of the effective mechanism of marketing activities and their mutual consistency.

Factors $\mathrm{F}_{\mathrm{i}}$ - the sum of criteria having corresponding coefficients Ki of manifestation (2):

$$
F_{i}=\frac{1}{n} \sum_{i=1}^{n} K_{i} .
$$

Given formulas (1) and (2), we have (3):

$$
P=m_{1}\left(\mathrm{~K}_{1}\right)+m_{2}\left(\mathrm{~K}_{2}\right)+m_{3}\left(\mathrm{~K}_{3}\right)+m_{4}\left(\mathrm{~K}_{4}\right)+m_{5}\left(\mathrm{~K}_{5}\right)+m_{6}\left(\mathrm{~K}_{6}\right)
$$

We have chosen a survey method. A poll is a method of collecting sociological information about the object under study during direct (oral poll, interview) or indirect (written poll, questionnaire) communication between the interviewer and the respondent.

The development of a factor-criterion assessment model is based on the determination by experts by ranking the significance of the factor. Employees of organizations in the advertising industry were selected as experts. From the methods of expert evaluations, the rating method (the method of evaluative classification) and the method of points of evaluations were used. To assess the indicators $(\mathrm{K})$, we use the scale proposed by scientists:

$$
\begin{aligned}
& 0<\mathrm{K} \leq 0,249 \text { - insufficient level; } \\
& 0,25<\mathrm{K} \leq 0,49 \text { - satisfactory level; } \\
& 0,5<\mathrm{K} \leq 0,749 \text { - sufficient level; } \\
& 0,75<\mathrm{K} \leq 1 \text { - high level. }
\end{aligned}
$$

We have combined the random principle of selection with the purposeful one in the context of ensuring that basic conditions are met. The random sample provided a high level of representativeness with probabilities approaching their distribution in the general population, and allows you to determine the employees who will be subject to the survey. In turn, targeted selection provided a sufficient level of reliability and validity with probabilities. This selection will ensure stability and fertility in the conclusions regarding the general population, and will determine the number of respondents. Targeted sampling is based on the quota method, that is, proportionality. This method uses information about the most important proportions of the general population.

One of the main problems is the development of an algorithm for converting the parameters of an object into indicators of its quality and, in particular, a targeted search for that minimum set of properties (indicators) that form the quality of an object. The problem of choice is to identify certain groups of indicators that meet the requirements of their necessity, sufficiency and independence. To solve this problem, a functionaltypological analysis can be used, based on considering quality as a system: they distinguish external consumer qualities (properties), by which a conclusion is made about the suitability of a product (service) to satisfy certain needs in accordance with its purpose, and internal consumer qualities, determine external qualities and characterize an object (created and operated), which has a structure of interrelated physical properties of its constituent elements. After processing the data and bringing them into a single system of calculation, the following ranked series of weight and significance of indicators were obtained (Table 1).

Based on the data of the survey, the priority criteria for assessing the effectiveness of the mechanism of marketing activities of organizations in the advertising industry are given in the following sequence: first place the element of the effectiveness of relations (24\%); Second - Leverage Effectiveness Element (20\%) and Principles Compliance Element (20\%); third - Element of the effectiveness of the marketing information system $(15 \%)$; the fourth - the element of effectiveness of the regulatory framework $(11.7 \%)$; fifth - Element of effectiveness of methods $(9.3 \%)$

So, the greatest influence on the integral indicator of the state of effectiveness of the effective mechanism of marketing activities of organizations in the advertising industry has the Element of the effectiveness of relations. On the rating scale, all indicators are at a sufficient level from 0.5 to 0.749 , except for the indicator of the effectiveness of leverage (satisfactory level)

According to the results of calculations, the state of effectiveness of the organizational mechanism for ensuring the effectiveness of the marketing activities of organizations in the advertising industry is estimated at $59.1 \%$ and is at a sufficient level. But such a level of the indicator indicates that the existing mechanism is characterized by imperfection and requires improvement. 
Table 1. Model for assessing the effectiveness of an effective mechanism for ensuring the marketing activities of organizations

\begin{tabular}{|c|c|c|}
\hline Element & $\begin{array}{l}\text { Ranking } \\
\text { criteria by } \\
\text { their } \\
\text { importance }\end{array}$ & $\begin{array}{l}\text { Weight of } \\
\text { factor }\end{array}$ \\
\hline $\begin{array}{l}\text { Leverage } \\
\text { performance } \\
\text { element }\left(\mathrm{m}_{1}\right)\end{array}$ & 0,2 & 0,46 \\
\hline $\begin{array}{l}\text { Compliance } \\
\text { element }\left(\mathrm{m}_{2}\right)\end{array}$ & 0,2 & 0,65 \\
\hline $\begin{array}{l}\text { Method } \\
\text { Performance } \\
\text { Element }\left(\mathrm{m}_{3}\right)\end{array}$ & 0,093 & 0,72 \\
\hline $\begin{array}{l}\text { Element } \\
\text { provision of } \\
\text { regulatory a } \\
\text { framework }\left(\mathrm{m}_{4}\right)\end{array}$ & 0,117 & 0,53 \\
\hline $\begin{array}{l}\text { Marketing } \\
\text { Information System } \\
\text { Performance } \\
\text { Element }\left(\mathrm{m}_{5}\right)\end{array}$ & 0,15 & 0,67 \\
\hline $\begin{array}{l}\text { Relationship } \\
\text { Performance } \\
\text { Element }\left(\mathrm{m}_{6}\right)\end{array}$ & 0,24 & 0,58 \\
\hline $\begin{array}{l}\text { Integral indicator of } \\
\text { the state of } \\
\text { effectiveness of the } \\
\text { effective } \\
\text { mechanism of } \\
\text { marketing activities } \\
\text { of organizations in } \\
\text { the advertising } \\
\text { industry }\end{array}$ & \multicolumn{2}{|c|}{0,591} \\
\hline
\end{tabular}

Summing up, we note that the presented system of indicators will make it possible to conduct a comprehensive assessment of the state of the effectiveness of an effective mechanism for ensuring the effectiveness of the marketing activities of organizations in the advertising industry and determine ways to improve it.

The management of organizations in the advertising industry has a real opportunity to use this information to make quality decisions to better manage the organization and improve their level of quality. The results of the assessment do not reflect the aggregate value of the effectiveness of an effective mechanism for ensuring the effectiveness of marketing activities of organizations in the advertising industry, however, they allow us to determine its state, in particular, the ability to be used not for financial support of current expenses, but for the implementation of development projects for organizations in the advertising industry.

Based on the results of diagnostics of modern development trends, assessment of the effectiveness of marketing activities and analysis of the effectiveness of an effective mechanism for ensuring the effectiveness of marketing activities of organizations in the advertising industry, the need for an integrated approach was identified.

This need, in our opinion, can be realized by building a structural-component approach to increasing the effectiveness of the marketing activities of organizations in the advertising industry. For the purpose of consistency of organizational features (objects and subjects of management of marketing activities) and economic elements (levers, principles, methods, regulatory support and marketing information system) of the mechanism for ensuring the effectiveness of marketing activities of organizations in the advertising industry is an integral part of any relationship of such organizations, we propose to conduct his assessment. Structuring an effective mechanism for ensuring the effectiveness of marketing activities of organizations in the advertising industry is the basis for a scientific and methodological approach to its assessment. Determination of the influence and connection of all components of this mechanism will allow to determine methods of ensuring its effectiveness and ways of improvement. Therefore, to solve this problem, it is necessary to determine the main provisions of the concept based on a structural-component approach to increasing the effectiveness of marketing activities, which will take into account the peculiarities of organizations in the advertising industry.

In our opinion, the structural-component approach to increasing the effectiveness of marketing activities of organizations in the advertising industry is based on determining the features of an effective mechanism to ensure the effectiveness of such activities of organizations in the advertising industry and assessing its effectiveness; the application of the hierarchy analysis method for ranking criteria and performance indicators and their modeling based on the integral development indicator, contributed to the development and implementation of a marketing development strategy in the activities of organizations in the advertising industry.

Evaluation of the effectiveness of the marketing activities of organizations in the advertising industry provides for a combined accounting of results:

- assessing the development trends of marketing activities of organizations in the advertising industry (Ukrainian and world experience)

- assessment of criteria and indicators of the effectiveness of marketing activities; 
- evaluating the effectiveness of an effective mechanism for ensuring the effectiveness of marketing activities based on the qualimetry method.

The results of the assessment serve as a basis for determining ways to improve the effectiveness of the marketing activities of organizations in the advertising industry based on:

- optimization of strategic directions and determining the level of their promotion of the effectiveness of marketing activities based on the method of analysis of hierarchies;

- modeling the effectiveness of marketing activities based on an integral development indicator (using the method of expert assessments and taxonomic methods)

- development and implementation of a marketing development strategy in the activities of organizations.

\section{CONCLUSIONS}

The organization of the activities of domestic organizations today requires reasonable rational actions, since not only the external environment, but also the organizations themselves and their product offer under the influence of time and circumstances change significantly. For each organization, the issues of creating, maintaining and strengthening competitive positions in the long term are especially acute; it is impossible, in particular, without developing a marketing mechanism to ensure the competitiveness of products and its effective functioning.

Modern business is characterized by a high degree of competition in the market. Competition, in turn, implies rivalry in a particular market between individual legal entities or individuals (competitors) interested in achieving the same goal. From an organizational perspective, this goal is to maximize profits by building customer loyalty. Increasing the rigidity of methods and forms of manifestation of competition, accelerating the pace of changes in market parameters have caused an objective need to develop and implement in Ukrainian organizations fundamentally new approaches to improving the management of the competitiveness of an organization and its products.

Organizations and can be characterized as competitive if it possesses and effectively uses manifestations of superiority over competitors in different areas of the market.

At the same time, the issues of marketing support for the competitiveness of organizations' products and the practical use of balanced marketing tools, taking into account the specifics of the industry, need to be adapted to the current stage of economic development and further scientific justification. This is due to the fact that an increase in the level of complexity of the market as a whole and the behavior of each entity, in particular, necessitates a review of the effectiveness of existing ones and the development of new, more effective, in a dynamic environment, marketing activities and programs within the framework of the marketing concept of the organization.

In the formation of the marketing mechanism for the development of an organization, it is imperative to take into account the general patterns and approaches that are characteristic of the management of any economic systems. Given the current trends in changes in the economic, political, social, scientific, environmental, the degree and number of problems in the management of the organization is increasing, which will require the calculation and analytical support of decisions.

\section{REFERENCES}

[1] Arend, R.J. (2013), "The business model: Present and future-Beyond a skeumorph", Strategic Organization, № 11 (4), pp. 390-402. DOI: https://doi.org/10.1177/1476127013499636.

[2] Casadesus-Masanell, R., \& Ricart, J.E. (2010), "From strategy to business models and onto tactics”, Long Range Planning, № 43 (2), pp. 195 215.

DOI: https://doi.org/10.1016/j.lrp.2010.01.004.

[3] Coombes, P.H., \& Nicholson, J.D. (2013), "Business models and their relationship with marketing: A systematic literature review", Industrial Marketing Management, № 42 (5), pp. 656-664.

DOI: https://doi.org/10.1016/j.indmarman.2013.05.005.

[4] Demil, B., \& Lecocq, X. (2010), "Business model evolution: In search of dynamic consistency", Long Range Planning, №43(2), pp. 227-246. DOI: https://doi.org/10.1016/j.lrp.2010.02.004.

[5] Fedorenko, I., \& Berthon, P. (2017), "Beyond the expected benefits: unpacking value co-creation in crowdsourcing business models", AMS Review, № 7(3-4). DOI: https://doi.org/10.1007/s13162017-0106-7.

[6] Foss, N.J. \& Saebi, T. (2017), "Fifteen years of research on business model innovation: How far have we come, and where should we go?" Journal of Management, № 43(1), pp. 200-227. DOI: https://doi.org/10. 1177/0149206316675927.

[7] Massa, L. Tucci, C. \& Afuah, A. (2017), “A critical assessment of business model research", Academy of Management Annals, № 11(1), pp. 73- 104. DOI: https://doi.org/10.5465/annals.2014.0072.

[8] Nystrom, A.G. \& Mustonen, M. (2017), “The dynamic approach to business models", AMS 
Review, № 7(3-4). DOI: https://doi.org/10.1007/s13162-017-0103-X

[9] Sorescu, A. (2017), "Data-Driven Business Model Innovation", Journal of Product Innovation Management, № 34(5), pp. 691-696. DOI: https://doi.org/ 10.1111/jpim.12398.

[10] Teece, D.J. (2010), "Business models, business strategy and innovation", Long Range Planning, №43(2), pp. 172-194. DOI: https://doi.org/10.1016/j.lrp. 2009.07.003.

[11] Eniafe Festus Ayetiran and Adesesan Barnabas Adeyemo (2012), “A Data Mining-Based Response Model for Target Selection in Direct Marketing", International Journal of Information Technology and Computer Science, № 1, pp. 9-18. DOI: 10.5815/ijitcs.2012.01.02.

[12] Shyam R. Sihare (2017), "Image-based Digital Marketing", International Journal of Information Engineering and Electronic Business, №5, pp. 1017. DOI: 10.5815/ijieeb.2017.05.02.

[13] Shyam R. Sihare (2018), "Roles of E-content for E-business: Analysis", International Journal of Information Engineering and Electronic Business, №1, pp. 24-30. DOI: 10.5815/ijieeb.2018.01.04.

[14] Kamala. K. Hashimova (2017), “Analysis Method of Internet Advertising-Marketing Information's Dynamic Changes", International Journal of Information Engineering and Electronic Business, №5, pp. 28-33. DOI: 10.5815/ijieeb.2017.05.04 